\title{
Actinopolymorpha rutila sp. nov., isolated from a forest soil
}

\author{
Correspondence \\ Wen-Jun Li \\ wjli@ynu.edu.cn \\ or \\ liact@hotmail.com
}

\author{
Yong-Xia Wang, ${ }^{1}$ Yu-Oin Zhang, ${ }^{1,2}$ Li-Hua Xu ${ }^{1}$ and Wen-Jun Li ${ }^{1,3}$ \\ ${ }^{1}$ The Key Laboratory for Microbial Resources of the Ministry of Education, PR China, and \\ Laboratory for Conservation and Utilization of Bio-Resources, Yunnan Institute of Microbiology, \\ Yunnan University, Kunming, 650091, PR China \\ ${ }^{2}$ Institute of Medicinal Biotechnology, Chinese Academy of Medical Sciences \& Peking Union \\ Medical College, Beijing 100050, PR China \\ ${ }^{3}$ Guangdong Key Laboratory of Marine Materia Medica, South China Sea Institute of Oceanology, \\ Chinese Academy of Sciences, Guangzhou 510301, PR China
}

The genus Actinopolymorpha was established by Wang et al. (2001) and it was placed within the family Nocardioidaceae (Nesterenko et al., 1985). At the time of writing, the family Nocardioidaceae comprises the genera Nocardioides Prauser et al. 1976 (type genus), Aeromicrobium Miller et al. 1991, Kribbella Park et al. 1999, Marmoricola Urzì et al. 2000, Actinopolymorpha Wang et al. 2001 and Jiangella Song et al. 2005. During the course of research into unknown actinomycetes, an Actinopolymorpha-like strain (YIM $45725^{\mathrm{T}}$ ) was isolated from a forest soil collected in Yunnan Province, south-west China. In order to determine the taxonomic position of this organism, we investigated its morphological, physiological and biochemical characteristics and analysed its chemotaxonomic composition and $16 \mathrm{~S}$ rRNA gene sequence. The results indicated that strain YIM $45725^{\mathrm{T}}$ represents a novel species of the genus Actinopolymorpha.

Cultural characteristics of strain YIM $45725^{\mathrm{T}}$ were determined by using 14-day-old cultures grown at $28{ }^{\circ} \mathrm{C}$

The GenBank/EMBL/DDBJ accession number for the $16 \mathrm{~S}$ rRNA gene sequence of strain YIM $45725^{\top}$ is EF601829.

Scanning electron and light micrographs of cells of strain YIM $45725^{\top}$ and a phylogenetic tree based on a comparative 16S rRNA gene sequence analysis, showing the relationships between strain YIM $45725^{\top}$ and related taxa, are available with the online version of this paper. on International Streptomyces Project (ISP; Shirling \& Gottlieb, 1966) media 2, 3, 4 and 5, Czapek's agar plates (Pridham \& Lyons, 1980), potato agar and nutrient agar. Colony colour was determined based on Kelly (1964). Morphological observations of cultures after incubation at $28{ }^{\circ} \mathrm{C}$ for 12 and 30 days on ISP 2 medium were made by light microscopy (BH-2; Olympus) and scanning electron microscopy (XL30; Philips).

Strain YIM $45725^{\mathrm{T}}$ had morphological properties consistent with those of the genus Actinopolymorpha. The novel isolate formed branched hyphae of uneven thickness that fragmented into short chains or aggregates in the early stages of growth. The branched substrate mycelia later exhibited varied degrees of fragmentation, with short to elongated rod-like elements or V-shaped elements, and in the later stages of growth, poorly formed aerial hyphae were observed on ISP 2 medium. Spores or sporangia were not observed (see Supplementary Fig. S1 in IJSEM Online). Colonies developed on the tested media within 3-4 days were raised and varied from smooth to rugose. Strain YIM $45725^{\mathrm{T}}$ grew well on ISP 2 and 5 media and potato agar and moderately well on ISP 3 and 5 media, Czapek's agar plates and nutrient agar. Strain YIM $45725^{\mathrm{T}}$ developed pink orange-yellow to deep orange-yellow colony colours on all media tested (Table 1), but no diffusible pigments were produced. 
Table 1. Cultural characteristics of strain YIM $45725^{\top}$

Diffusible pigments were not produced on any of the media listed. ISP, International Streptomyces project.

\begin{tabular}{|llll|}
\hline Medium & Growth & Aerial mycelium & Substrate mycelium \\
\hline Yeast extract-malt extract (ISP medium 2) & Good & Poor & Deep orange-yellow \\
Oatmeal agar (ISP medium 3) & Moderate & Absent & Brilliant orange-yellow \\
Inorganic salt-starch agar (ISP medium 4) & Moderate & Absent & Pink orange-yellow \\
Glycerol-asparagine (ISP medium 5) & Good & Absent & Brilliant orange-yellow \\
Czapek's agar & Moderate & Absent & Brilliant orange-yellow \\
Nutrient agar & Moderate & Absent & Pink orange-yellow \\
Potato agar & Good & Absent & Deep orange-yellow \\
\hline
\end{tabular}

Physiological characteristics, including sugar fermentation analyses, utilization of organic acids and carbohydrates and hydrolysis or decomposition of adenine, hypoxanthine, tyrosine, xanthine, casein, aesculin and urea, were evaluated as described by Gordon et al. (1974) after incubation at $28{ }^{\circ} \mathrm{C}$ for 15 days; the type strain of Actinopolymorpha singaporensis was also employed in these studies. Determination of enzyme activities was carried out by using the API ZYM test system (bioMérieux) according to the manufacturer's recommendations. Catalase activity was detected based on the production of bubbles after the addition of a drop of $3 \%$ $\mathrm{H}_{2} \mathrm{O}_{2}$. Oxidase activity was determined based on the oxidation of $1 \% p$-aminodimethylaniline oxalate. Growth at different temperatures $\left(4,15,20,28,37,45\right.$ and $\left.50{ }^{\circ} \mathrm{C}\right)$, $\mathrm{NaCl}$ concentrations $(1,3,5,7$ and $10 \%)$ and $\mathrm{pH}(4.0-$ 10.0) was assessed after incubation at $28{ }^{\circ} \mathrm{C}$ for $7-15$ days on ISP 2 medium.

Good growth occurred at $28{ }^{\circ} \mathrm{C}$, but no growth occurred below 15 or above $37{ }^{\circ} \mathrm{C}$. Growth was observed between pH 6 and 8 and at up to $5 \% \mathrm{NaCl}$. Strain YIM $45725^{\mathrm{T}}$ was oxidase- and catalase-positive. Differential physiological features between strain YIM $45725^{\mathrm{T}}$ and $A$. singaporensis IM $7744^{\mathrm{T}}$ are given in Table 2; other phenotypic characteristics of strain YIM $45725^{\mathrm{T}}$ are given in the species description.

The amino acid and sugar patterns of the cell wall were determined as described by Staneck \& Roberts (1974). Polar lipids were extracted as described by Minnikin et al. (1979) and identified by two-dimensional TLC and after spraying with specific reagents (Collins \& Jones, 1980). Menaquinones were determined according to the procedures of Collins et al. (1977) and were analysed by HPLC as described by Tamaoka et al. (1983). Biomass for quantitative fatty acid analysis was prepared by scraping cells from TSB agar plates [trypticase soy broth (BBL), $3 \%(\mathrm{w} / \mathrm{v})$; Bacto agar (Difco), $1.5 \%(\mathrm{w} / \mathrm{v})$ ] that had been incubated for 5 days at $28{ }^{\circ} \mathrm{C}$. The fatty acids were extracted, methylated and analysed by using the standard MIDI (Microbial Identification) system (Sasser, 1990; Kämpfer \& Kroppenstedt, 1996). The G $+\mathrm{C}$ content of the genomic DNA was determined by HPLC according to Mesbah et al. (1989).
Chemotaxonomically, strain YIM $45725^{\mathrm{T}}$ contained chemical markers supporting its assignment to the genus Actinopolymorpha. The cell wall contained LL-diaminopimelic acid as well as ribose, glucose and galactose. Strain YIM $45725^{\mathrm{T}}$ could be differentiated from the type strain of A. singaporensis based on the absence of rhamnose and presence of galactose. MK-9 $\left(\mathrm{H}_{4}\right)$ was the predominant menaquinone. MK-9 $\left(\mathrm{H}_{6}\right), \mathrm{MK}-10\left(\mathrm{H}_{4}\right)$ and $\mathrm{MK}-10\left(\mathrm{H}_{6}\right)$ were also present. In contrast, the predominant menaquinone of $A$. singaporensis was $\mathrm{MK}-9\left(\mathrm{H}_{6}\right)$. Phospholipids consisted of phosphatidylinositol mannosides, phosphatidylinositol, diphosphatidylglycerol and phosphatidylglycerol (type PI pattern sensu Lechevalier et al., 1981). The major fatty acids $(>10 \%)$ in whole-cell methyl esters were iso- $\mathrm{C}_{16: 0}(22.36 \%)$, iso- $\mathrm{C}_{15: 0}(22.09 \%)$ and iso- $\mathrm{C}_{16: 1} \mathrm{H}$ $(21.57 \%)$. The DNA G $+\mathrm{C}$ content of strain YIM $45725^{\mathrm{T}}$ was $67.7 \mathrm{~mol} \%$.

Extraction of genomic DNA and PCR amplification for $16 \mathrm{~S}$ rRNA gene sequence analysis were performed as described by Li et al. (2007). The 16S rRNA gene sequence of strain YIM $45725^{\mathrm{T}}$ was aligned with that of $A$. singaporensis IM $7744^{\mathrm{T}}$ and of members of related genera retrieved from GenBank by using the CLUSTAL_X 1.8 program (Thompson et al., 1997) based on BLAST results in the NCBI. Subsequently, phylogenetic analysis was performed by using the MEGA3 software package (Kumar et al., 2004). Distances were calculated by using distance options according to the Kimura two-parameter model (Kimura, 1980, 1983) and clustering was performed with the neighbour-joining method (Saitou \& Nei, 1987). Bootstrap analysis (1000 resamplings) was used to evaluate the tree topology of the neighbour-joining data (Felsenstein, 1985).

To determine the phylogenetic position of strain YIM $45725^{\mathrm{T}}$, the almost-complete $16 \mathrm{~S}$ rRNA gene sequence (1429 nt) was determined and subjected to comparative analysis. These comparisons showed clearly that strain YIM $45725^{\mathrm{T}}$ was a member of the genus Actinopolymorpha within the family Nocardioidaceae. Strain YIM $45725^{\mathrm{T}}$ showed the highest $16 \mathrm{~S}$ rRNA gene sequence similarity to A. singaporensis IM $7744^{\mathrm{T}}(99.4 \%)$. Significantly lower levels of similarity $(<93.0 \%)$ were found to all other taxa investigated. The neighbour-joining phylogenetic tree is 
Table 2. Differential characteristics between strain YIM $45725^{\top}$ and its closest phylogenetic neighbour, Actinopolymorpha singaporensis IM $7744^{\top}$

Both strains are positive for the hydrolysis of casein, hypoxanthine, xanthine, glycine, L-proline, Tween 20 and gelatin, but are negative in tests for the degradation of Tween 80 , adenine, cellulose and starch, and for the utilization of D-glucose, D-fructose, maltose, dextrin, salicin, malonate, L-rhamnose, D-xylose, D-mannitol, sucrose, myoinositol and glycerol as carbon sources. Both are positive for acid production from D-fructose, sucrose, glucose and D-xylose. +, Positive; -, negative.

\begin{tabular}{|c|c|c|}
\hline Characteristic & $\begin{array}{c}\text { YIM } \\
45725^{T}\end{array}$ & $\begin{array}{l}\text { A. singaporensis } \\
\text { IM } 7744^{\mathrm{T}}\end{array}$ \\
\hline \multicolumn{3}{|c|}{ Utilization of substrate as carbon source } \\
\hline Raffinose & + & - \\
\hline Sorbitol & - & + \\
\hline Lactose & + & - \\
\hline Cellobiose & + & - \\
\hline D-Arabinose & + & - \\
\hline Sodium citrate & - & + \\
\hline Sodium succinate & + & - \\
\hline \multicolumn{3}{|l|}{ Acid production from: } \\
\hline Mannose & + & - \\
\hline Maltose & + & - \\
\hline L-Rhamnose & - & + \\
\hline Sorbitol & - & + \\
\hline myo-Inositol & - & + \\
\hline D-Galactose & - & + \\
\hline Milk coagulation & - & + \\
\hline Milk peptonization & - & + \\
\hline Reduction of nitrate & - & + \\
\hline Growth temperature range $\left({ }^{\circ} \mathrm{C}\right)$ & $15-37$ & $25-37$ \\
\hline
\end{tabular}

available as Supplementary Fig. S2 in IJSEM Online. It is evident from this tree that strain YIM $45725^{\mathrm{T}}$ forms a distinct cluster with A. singaporensis IM $7744^{\mathrm{T}}$ in the family Nocardioidaceae.

Given the high level of $16 \mathrm{~S}$ rRNA gene sequence similarity between strain YIM $45725^{\mathrm{T}}$ and A. singaporensis $\mathrm{IM} 7744^{\mathrm{T}}$, DNA-DNA hybridization studies were performed according to the methods described by He et al. (2005) to confirm whether strain YIM $45725^{\mathrm{T}}$ represented a distinct species. Strain YIM $45725^{\mathrm{T}}$ displayed a relatively low level of DNADNA relatedness (mean of $33.2 \%$ ) to A. singaporensis KCTC $19907^{\mathrm{T}}\left(=\mathrm{IM} 7744^{\mathrm{T}}\right)$, a result that is below the cutoff point recommended by Wayne et al. (1987) for circumscription of bacterial genomic species, and confirmed the separation of strain YIM $45725^{\mathrm{T}}$ from its nearest phylogenetic neighbour. This was also supported based on some differential phenotypic characteristics between the two taxa, which are detailed in Table 2.

The genotypic and phenotypic data presented indicate that strain YIM $45725^{\mathrm{T}}$ represents a novel species of the genus Actinopolymorpha, for which the name Actinopolymorpha rutila sp. nov. is proposed.

\section{Description of Actinopolymorpha rutila sp. nov.}

Actinopolymorpha rutila (ru.ti'la. L. fem. adj. rutila red inclining to golden-yellow, referring to the colour of colonies produced).

Grows at $15-37{ }^{\circ} \mathrm{C}$ (optimum $28{ }^{\circ} \mathrm{C}$ ), $\mathrm{pH} 6-8$ and in the presence of up to $5 \% \mathrm{NaCl}$ on ISP 2 medium. Colonies develop well within 3-4 days and vary from smooth to rugose; colony colour is dependent on the medium used for growth, varying from pink orange-yellow to deep orange-yellow. Diffusible pigments are not formed. Forms branched substrate mycelia of uneven thickness that fragment into short chains or aggregates in the early stages of growth; branched hyphae later exhibit varied degrees of fragmentation with short to elongated rod-like elements or V-shaped elements; in the later stages of growth, poorly formed aerial hyphae are seen on ISP 2 agar. Spores and sporangia are absent. Gram-positive. Catalase- and oxidase-positive. $\mathrm{H}_{2} \mathrm{~S}$ is not produced. In addition to the properties shown in Table 2, assimilates ribose, mannose, melibiose, maltose, melezitose, dextrin, xylitol, adonitol, Dgalactose, salicin and malonate as sole carbon sources, but not dulcitol, arabitol, acetate, citrate or oxalate. Hydrolyses hypoxanthine, xanthine, casein, L-alanine, L-asparagine, Larginine, glycine, L-histidine, L-hydroxyproline, phenylalanine, L-proline, L-cysteine, L-valine, urea and Tween 20, but not Ltyrosine, adenine, glucosamine, Tween 60 , Tween 80 , cellulose or DNA. Acid is produced from D-fructose, ribose, fucose, raffinose, sucrose, erythritol, glucose and D-xylose. Positive for the enzymes alkaline phosphatase, esterase (C4), esterase lipase (C8), $\alpha$-glucosidase, $\beta$-glucosidase, $\alpha$-galactosidase, $\beta$ galactosidase and $\alpha$-mannosidase, but negative for $N$-acetyl$\beta$-glucosaminidase, lipase (C14), $\beta$-glucuronidase, acid phosphatase, naphthol-AS-BI-phosphohydrolase, leucine arylamidase, cystine arylamidase, valine arylamidase, $\alpha$-fucosidase, chymotrypsin and trypsin. Tests positive for gelatin, but negative for nitrate reduction, starch hydrolysis, milk coagulation and peptonization. The diagnostic amino acid of the peptidoglycan is LL-diaminopimelic acid. Cell-wall hydrolysates contain ribose, glucose and galactose. MK- $9\left(\mathrm{H}_{4}\right)$ is the predominant menaquinone; MK- $9\left(\mathrm{H}_{6}\right), \mathrm{MK}-10\left(\mathrm{H}_{4}\right)$ and MK$10\left(\mathrm{H}_{6}\right)$ are also present. Phospholipids consist of phosphatidylinositol mannosides, phosphatidylinositol, diphosphatidylglycerol and phosphatidylglycerol. The major cellular fatty acids $(>1 \%)$ are iso- $\mathrm{C}_{16: 0}(22.36 \%)$, iso- $\mathrm{C}_{15: 0}(22.09 \%)$, iso$\mathrm{C}_{16: 1} \mathrm{H}(21.57 \%)$, iso- $\mathrm{C}_{17: 0}(8.92 \%)$, anteiso- $\mathrm{C}_{17: 0}(8.30 \%)$, iso- $\mathrm{C}_{14: 0}$ 3-OH (3.80\%), anteiso- $\mathrm{C}_{15: 0}(3.66 \%)$, iso- $\mathrm{C}_{14: 0}$ (2.59\%), iso- $\mathrm{C}_{18: 1} \mathrm{H}(1.64 \%), \mathrm{C}_{15: 0} 3-\mathrm{OH}(1.48 \%)$ and $10-$ methyl $\mathrm{C}_{17: 0}(1.06 \%)$. The DNA G $+\mathrm{C}$ content of the type strain is $67.7 \mathrm{~mol} \%$.

The type strain, YIM $45725^{\mathrm{T}} \quad(=$ CCTCC AA $206004^{\mathrm{T}}=$ DSM $18448^{\mathrm{T}}$ ), was isolated from a soil sample collected in Yunnan Province, south-west China.

\section{Acknowledgements}

This research was supported by the National Basic Research Program of China (No. 2004CB719601), the National Natural Science Foundation of China (Nos. 30560001, 30600001), the Yunnan 
Provincial International Cooperative Program (No. 2005GH21) and the Ministry of Science and Technology, PR China (2006DFA33550). W. J. L. was also supported by the Program for New Century Excellent Talent in University (NCET).

\section{References}

Collins, M. D. \& Jones, D. (1980). Lipids in the classification and identification of coryneform bacteria containing peptidoglycans based on 2, 4-diaminobutyric acid. J Appl Bacteriol 48, 459-470.

Collins, M. D., Pirouz, T., Goodfellow, M. \& Minnikin, D. E. (1977). Distribution of menaquinones in actinomycetes and corynebacteria. $J$ Gen Microbiol 100, 221-230.

Felsenstein, J. (1985). Confidence limits on phylogenies: an approach using the bootstrap. Evolution 39, 783-791.

Gordon, R. E., Barnett, D. A., Handerhan, J. E. \& Pang, C. H. N. (1974). Nocardia coeliaca, Nocardia autotrophica, and the nocardin strain. Int J Syst Bacteriol 24, 54-63.

He, L., Li, W., Huang, Y., Wang, L. M., Liu, Z. H., Lanoot, B. J., Vancanneyt, M. \& Swings, J. (2005). Streptomyces jietaisiensis sp. nov., isolated from soil in northern China. Int J Syst Evol Microbiol 55, 1939-1944.

Kämpfer, P. \& Kroppenstedt, R. M. (1996). Numerical analysis of fatty acid patterns of coryneform bacteria and related taxa. Can J Microbiol 42, 989-1005.

Kelly, K. L. (1964). Inter-Society Color Council - National Bureau of Standards Color Name Charts Illustrated with Centroid Colors. Washington, DC: US Government Printing Office.

Kimura, M. (1980). A simple method for estimating evolutionary rates of base substitutions through comparative studies of nucleotide sequence. J Mol Evol 16, 111-120.

Kimura, M. (1983). The Neutral Theory of Molecular Evolution. Cambridge: Cambridge University Press.

Kumar, S., Tamura, K. \& Nei, M. (2004). MEGA 3: integrated software for molecular evolutionary genetics analysis and sequence alignment. Brief Bioinform 5, 150-163.

Lechevalier, M. P., Stern, A. E. \& Lechevalier, H. A. (1981). Phospholipids in the taxonomy of actinomycetes. Zentralbl Bakteriol Hyg Abt 1 (Suppl 11), 111-116.

Li, W. J., Xu, P., Schumann, P., Zhang, Y. Q., Pukall, R., Xu, L. H., Stackebrandt, E. \& Jiang, C. L. (2007). Georgenia ruanii sp. nov., a novel actinobacterium isolated from forest soil in Yunnan (China) and emended description of the genus Georgenia. Int J Syst Evol Microbiol 57, 1424-1428.

Mesbah, M., Premachandran, U. \& Whitman, W. B. (1989). Precise measurement of the $\mathrm{G}+\mathrm{C}$ content of deoxyribonucleic acid by highperformance liquid chromatography. Int J Syst Bacteriol 39, 159-167.

Miller, E. S., Woese, C. R. \& Brenner, S. (1991). Description of the erythromycin-producing bacterium Arthrobacter sp. strain NRRL B3381 as Aeromicrobium erythreum gen. nov., sp. nov. Int J Syst Bacteriol 41, 363-368.
Minnikin, D. E., Collins, M. D. \& Goodfellow, M. (1979). Fatty acid and polar lipid composition in the classification of Cellulomonas, Oerskovia and related taxa. J Appl Bacteriol 47, 87-95.

Nesterenko, O. A., Kvasnikov, E. I. \& Nogina, T. M. (1985). Nocardioidaceae fam. nov., a new family of the order Actinomycetales Buchanan 1917. Mikrobiol Zh 47, 3-12.

Park, Y. H., Yoon, J. H., Shin, Y. K., Suzuki, K., Kudo, T., Seino, A., Kim, H. J., Lee, J. S. \& Lee, S. T. (1999). Classification of 'Nocardioides fulvus' IFO 14399 and Nocardioides sp. ATCC 39419 in Kribbella gen. nov., as Kribbella flavida sp. nov. and Kribbella sandramycini sp. nov. Int J Syst Bacteriol 49, 743-752.

Prauser, H. (1976). Nocardioides, a new genus of the order Actinomycetales. Int J Syst Bacteriol 26, 58-65.

Pridham, T. G. \& Lyons, A. J. (1980). Methodologies for Actinomycetales with special reference to streptomycetes and streptoverticillia. In Actinomycete Taxonomy, Special publication no. 6, pp. 153-224. Edited by A. Dietz \& D. W. Thayer. Arlington, VA: Society for Industrial Microbiology.

Saitou, N. \& Nei, M. (1987). The neighbor-joining method: a new method for reconstructing phylogenetic trees. Mol Biol Evol 4, 406425.

Sasser, M. (1990). Identification of bacteria by gas chromatography of cellular fatty acids, MIDI Technical Note 101. Newark, DE: MIDI Inc.

Shirling, E. B. \& Gottlieb, D. (1966). Methods for characterization of Streptomyces species. Int J Syst Bacteriol 16, 313-340.

Song, L., Li, W. J., Wang, Q. L., Chen, G. Z., Zhang, Y. S. \& Xu, L. H. (2005). Jiangella gansuensis gen. nov., sp. nov., a novel actinomycete from a desert soil in north-west China. Int J Syst Evol Microbiol 55, 881-884.

Staneck, J. L. \& Roberts, G. D. (1974). Simplified approach to identification of aerobic actinomycetes by thin layer chromatography. Appl Microbiol 28, 226-231.

Tamaoka, J., Katayama-Fujimura, Y. \& Kuraishi, H. (1983). Analysis of bacterial menaquinone mixtures by high performance liquid chromatography. J Appl Bacteriol 54, 31-36.

Thompson, J. D., Gibson, T. J., Plewniak, F., Jeanmougin, F. \& Higgins, D. G. (1997). The CLUSTAL_X windows interface: flexible strategies for multiple sequence alignment aided by quality analysis tools. Nucleic Acids Res 25, 4876-4882.

Urzì, C., Salamone, P., Schumann, P. \& Stackebrandt, E. (2000). Marmoricola aurantiacus gen. nov., sp. nov., a coccoid member of the family Nocardioidaceae isolated from a marble statue. Int J Syst Evol Microbiol 50, 529-536.

Wang, Y. M., Zhang, Z. S., Xu, X. L., Ruan, J. S. \& Wang, Y. (2001). Actinopolymorpha singaporensis gen. nov., sp. nov., a novel actinomycete from the tropical rainforest of Singapore. Int J Syst Bacteriol 51, 467-473.

Wayne, L. G., Brenner, D. J., Colwell, R. R., Grimont, P. A. D., Kandler, O., Krichevsky, M. I., Moore, L. H., Moore, W. E. C., Murray, R. G. E. \& other authors (1987). International Committee on Systematic Bacteriology. Report of the ad hoc committee on reconciliation of approaches to bacterial systematics. Int J Syst Bacteriol 37, 463-464. 